\title{
Étrend-kiegészítốk és ergogén anyagok a sporttáplálkozásban Place and role of sietary supplements and ergogenic acid in sport nutrition
}

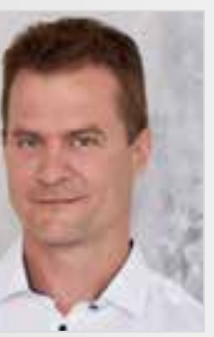

Szerzôk/Authors: DR. HABIL. FRITZ PÉTER egyetemi docens/ PETER FRITZ DR. HABIL. associate professor Ferencvárosi Torna Club, Miskolci Egyetem E-mail:pfritz@hotmail.hu. Tudományos tevékenysége: doktori iskolában témavezetố Scientific activity: supervisor in doctoral school Föbb kutatási terület: sporttáplálkozás, rekreáció Main areas of research: sports nutrition, recreation

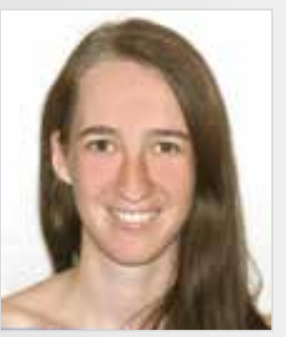

KISS ANNA/ANNA KISS Szent István Egyetem Élelmiszertudományi Kar Szent István University, Faculty of Food Science E-mail: kiss.anna891@gmail.com

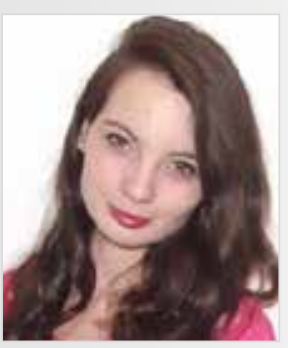

PFEIFFER LAURA/ LAURA PFEIFFER

Szent István Egyetem, Élelmiszertudományi Kar Szent István University, Faculty of Food Science E-mail:

laura.pfeiffer23@gmail.com

ÖSSZEFOGLALÁS: Az étrendkiegészítő-fogyasztás prevalenciája a sport minden szintjén nagy és egyre növekvő tendenciát mutat. Az étrend-kiegészítők és ergogén anyagok használatának oka lehet a mikrotápanyag-hiány pótlása, energia- és makrotápanyag-ellátottság biztosítása, továbbá a közvetlen és közvetett teljesítménynövelés. Csupán kevés anyag teljesítményfokozó hatásáról van egyértelmű bizonyíték, ezek közé tartozik a koffein, a kreatin, a nátriumbikarbonát és az étrendi nitrátok. A koffein élénkítően hat, a központi idegrendszert, valamint a szív-ér rendszert stimulálja. Mérsékelt mennyiségú koffeinbevitel ( $\mathrm{kb} 3 \mathrm{mg} / \mathrm{ttkg}, 2$ csésze kávé) egyes sportágakban teljesítménymegőrző hatással bír. A kreatin mint ergogén anyag ígéretesnek tűnik, a nagymértékű, rövid idejű terhelésnek kitett teljesítménysportolók számára a kreatin teljesítménynövelő hatást kínál. A nátrium-bikarbonát növeli az extracelluláris pufferkapacitást, amely potenciálisan kedvező hatással van a rövid idejü, de a tartósan magas intenzitású edzést végzők teljesítményére. Étrend-kiegészítők fogyasztását megelőzően orvossal/táplálkozási szakemberrel való konzultáció szükséges a lehetséges kockázati tényezők kiszűrése és az étrend-kiegészítők biztonságos alkalmazása érdekében.

Kulcsszavak: étrend-kiegészítés, nátrium-bikarbonát, kreatin, koffein

ABSTRACT: The prevalence of dietary supplement consumption is big and shows a growing tendency. The usage of dietary supplements and ergogen substances are may be caused by supplement shortage of micronutrients, providing energy and macronutrients supply and direct and indirect performance enhancement. Only a few substances have clear evidence about their performance enchancing effects which belong to caffeine, creatine, sodium bicarbonate and dietary nitrates. Caffein has a stimulant effect on the central nerve system and stimulates the cardiovascular system. Moderate amounts of caffeine intake (about 2 cups of coffee) has a performance enahncing effect in certain sports. On the other hand, creatin, as an ergogenic substance, looks promising for high intensive volumen and short-term performance athletes, creatine has performance enhancing effects. The extracellulare buffer capacity is enhanced by sodium-bicarbonate, which has a potentially beneficial effect on short-term but persistently high intensity training for athletes. Before taking dietary supplements, consultation with a doctor/ nutritionist, it is necessary to eliminate possible risk factors and to ensure safe usage of dietary supplements.

Keywords: dietary supplementation, sodium bicarbonate, creatine, caffeine

\section{Étrend-kiegészítők \\ fogyasztása}

Az elmúlt tíz évben, világviszonylatban, rohamos ütemben növekedett mind felnőtt, rendszeresen nem sportoló fogyasztók, mind azoknak a sportolóknak a száma, akik étrend-kiegészítóket fogyasztanak. Az Egyesült Államokban készült országos táplálkozási felmérés (NHANES) adatai szerint a fogyasztók 10\%-a egynél több étrend-kiegészítőt használ, az étrendkiegészítő-fogyasztás az 1970-es évek óta 2000-ig folyamatosan nőtt, s jelenleg stagnál. A kutatás szerint a felnőtt lakosság minimum 50\%-a legalább alkalmanként fogyasztja ezeket a termékeket (Dickinson et al, 2014).

$\mathrm{Az}$ egyre növekvő étrendkiegészítő-fogyasztás a felnőtt lakosság mellet az élsportolókra is jellemző. Az étrend-kiegészítők piacának részeként a sportolóknak szánt étrend-kiegészítőkkel foglalkozó iparág az élelmiszeripar legdinamikusabban növekvő ágazatai között szerepel (NBJ, 2015). A 2014-ben vásárolt összes étrend-kiegészítő 28,4\%-a ebben az alszegmensben került értékesítésre.

Sok, sportolók számára készült étrend-kiegészító kifejlesztése nem nyugszik tudományos alapokon, ennek ellenére az élsportolók 85\%-a fogyasztja őket anélkül, hogy megbizonyosodná-

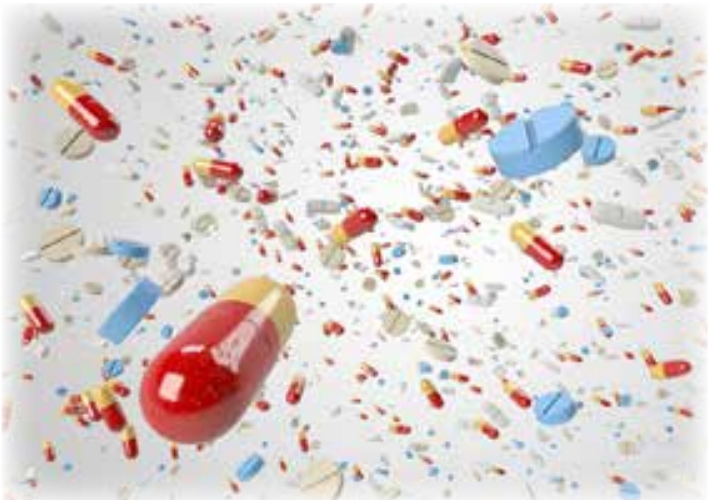

nak biztonságosságukról, legalitásukról (Knapik et al, 2015).

Napjainkban az élsportolók mellett egyre több szabadidő-sportoló is használ teljesítményfokozó szereket, azonban a viselkedés megértésére kevés kutatás történt.

\section{Az étrend-kiegészítők \\ szabályozása}

E termékkör meghatározása rendkívül bonyolult, jelenleg nem áll rendelkezésre az Európai Unió tagállamaiban általánosan elfogadott definíció sem az étrend-kiegészítókre vonatkozóan. A szakirodalmi források jelentős része továbbra 


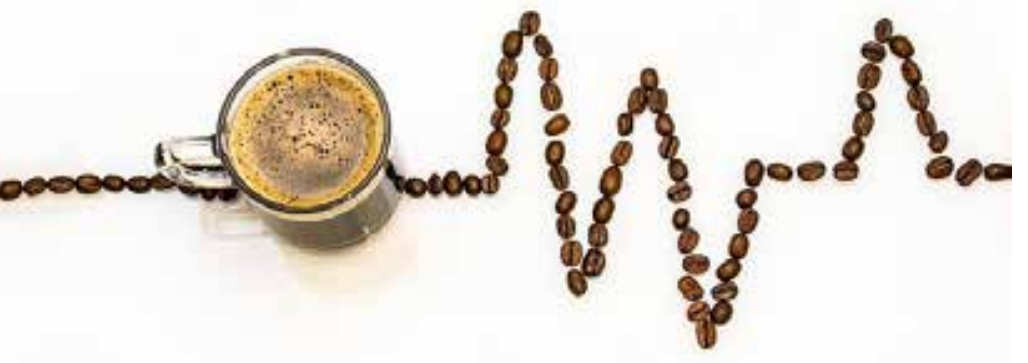

is az Egyesült Államok Élelmiszer- és Gyógyszer-ellenőrzési Hatóság meghatározását alkalmazza, amelynek értelmében ide tartoznak a hagyományos étrend kiegészítését szolgáló olyan élelmiszerek, amelyek koncentrált formában tartalmaznak tápanyagokat vagy egyéb táplálkozási vagy élettani hatással rendelkező anyagokat. Ezen termékek adagolt vagy adagolható formában kerülhetnek forgalomba. A sportolók körében és a köznyelvben a táplálék-kiegészítő elnevezés az általánosan használt kifejezés, az étrend-kiegészítőket az étrend-kiegészítőkről szóló 37/2004. (IV. 26.) rendelet szabályozza (Lugasi, 2014).

A sportolók számára összeállított termékek vonatkozásában nincs a Codex Alimentariushoz vagy a Magyar Élelmiszerkönyvhöz hasonló termékspecifikus szabályozás, ezért az étrend-kiegészítők piacát rendkívüli változatosság jellemzi, amely egyúttal számos kockázatot is jelent. Az élelmiszerekre, így az étrend-kiegészítőkre az uniós általános élelmiszerjog (178/2002/EK rendelete) vonatkozik, amely szerint az élelmiszer-ipari vállalkozásoknak gondoskodniuk kell termékeik biztonságos voltáról.

\section{Ergogén anyagok}

A piacon sok teljesítménynövelést ígérő készítmény található, ezeket a lehetséges teljesítménynövelő szereket úgynevezett „ergogén anyagoknak" nevezik. Ezeket a hatóanyagokat nemcsak a szervezet állítja elő, hanem táplálkozással is bevihetők. Az ergogén anyagok dúsítással történő kiegészítését szupplementációnak nevezzük. Az ergogén anyagok közé tartozik például az L-karnitin, a koffein, a taurin és a kreatin (Kerksick et al., 2018).

$\mathrm{Az}$ Ausztrál Sportintézet (AIS) a kiegészítőket a sportolók számára hatásuk és biztonságosságuk alapján klasszifikálta (1. táblázat), így gyors tájékozódást tesz lehetővé. Az egyes anyagok jelentősége és biztonságossága A-tól (jóváhagy/ajánl) D-ig (nem ajánlott/tiltott) csökken (Raschka \& Ruf, 2017).

\section{AIS csoport \\ klasszifikáció} speciális sportolói

1. táblázat: Az Ausztrál Sportintézet (AIS) étrend-kiegészítö és ergogén anyag klasszifikációja sportolók számára hatásuk és biztonságosságuk alapján

A

(Fogyasztásuk terhelés és különleges helyzet esetén ajánlható. Ezekben a szituációkban az étrend-kiegészítők a tudományos kutatásokban hatásosnak mutatkoztak.)

\section{B}

(Hatásukra nincs egyértelmú bizonyíték, AIS bevételüket kutatási megfigyelés alatt hagyja jóvá.)

\begin{tabular}{l|l} 
& • elágazó láncú aminosavak \\
& és más szabad \\
& aminosavak \\
C & Q10-koenzim \\
(Olyan kiegészítők, & citokróm c (enzim) \\
amelyek hatása nem & - gin zeng \\
bizonyított.) & - inozin \\
& • piruvát \\
& - oxigénnel dúsított víz
\end{tabular}

\section{D}

(Olyan kiegészítők, amelyek fogyasztása tilos (dopping lista).

\section{Koffein}

A koffein hatása 30-60 perc elteltével pszichológiai és fiziológiai szinten is megmutatkozik. A koffein egyrészt stimulálja a központi idegrendszert, valamint a szív-ér rendszert, ezzel növelve az éberséget és a koncentrálóképességet. Ez pozitívan hat a pszichomotorikus teljesítőképességre, ami azt jelenti, hogy javul a koordináció, a koncentráció és a reakció. Ehhez az egyidejüleg megnövekedett adrenalinkiáramlás is hozzájárul. Vitatott kérdés, hogy a fáradtság megjelenésének észlelése szubjektíve késleltethető-e. A második lehetséges teljesítménynövelő hatás azon állóképességi sportágak sportolói számára adódik, akiknél a teljesítményt a szénhidrátok hozzáférhetősége szabályozza. Az adrenalin és a koffein serkenti a zsírégetést, így az „értékes” szénhidrátok megtakarítására kerülhet sor. Ez a glikogénkímélő hatás eddig teljesítménysportolók körében volt megfigyelhető olyan laboratóriumi feltételek mellett, amelyben terhelés alatt 3-9 mg/ ttkg koffeinbevitelre került sor. Ez rendszerint 2-6 csésze kávénak felel meg. Új kutatások azonban azt mutatják, hogy csupán az étrend-kiegészítő formájában bevitt tiszta koffein növeli a zsírsavszintet.

Rövid idejü, 5 percen át tartó nagy intenzitású terhelés esetén a kutatások teljesítményjavulást mutatnak, amely során a fáradtság késleltetve lép fel. A koffein ebben az esetben támogató szerepet játszik akár élénkítő hatásmechanizmusa miatt, akár az izomzat anaerob körülmények közötti energiaszolgáltatására és összehúzódására gyakorolt, pontosan még nem tisztázott hatásának következtében. Ennek ellenére sprint (maximum $90 \mathrm{mp}$ ) esetén a koffein nem tünik hasznosnak.

A Doppingellenes Világszövetség (WADA) 2004-ben levette a koffeint a doppinglistáról. A koffeinbevitel további megfigyelése érdekében a vizeletben mérik a koffeinszintet, a határértéket azonban eltörölték. Az American College of Sport Medicine ajánlása szerint az optimális koffeinbevitel 3-6 $\mathrm{mg} / \mathrm{ttkg}$ terhelés előtt egy órával, ezzel a lehetséges mellékhatások (gyomor-bél rendszeri problémák, izomremegés, szívdobogás) minimálisra csökkenthetők.

\section{A koffeinbevitel mellékhatásai}

A koffein okozta kísérő jelenségek fellépése egyénenként rendkívül eltérő. Az olyan tünetek, mint gyomoridegesség, emésztési zavarok, fejfájás, álmatlanság, remegés vagy idegesség a sportolás előtti, 3-6 $\mathrm{mg} / \mathrm{ttkg}$-ot nem meghaladó be- 
vitel esetén rendszerint nem lépnek fel. Nagyobb adag bevitelekor (10-15 $\mathrm{mg} / \mathrm{ttkg}$ ) - ami koffeintablettával igen gyorsan elérhető - akár olyan veszélyes következménnyel járó, a sportolók számára végzetes mellékhatások jelennek meg, mint szívritmuszavar és az enyhe hallucináció.

\section{Kreatin}

A kreatinfoszfát $(K r P)$ gyorsan mozgósítható energiaforrás, az ATPnek, azaz az izom közvetlen energiaforrásának regenerálásában játszik szerepet. Jóllehet az ATP-KrP rendszer nagyon gyorsan képes energiát szolgáltatni, de csak rövid időn (másodpercektől pár percig) keresztül. Az emberi szervezet arginin, glicin és metionin segítségével képes a kreatin szintetizálására, amely elsősorban a májban képződik és 95\%-a az izomban raktározódik. A szervezet saját szintézise mellett kreatint a táplálékból is veszünk fel $(k b .1 \mathrm{~g})$, mely természetes körülmények között az állati eredetű élelmiszerekben, mint például a hús és a hal, található meg. A növényi eredetű élelmiszerek és a tejtermékek azonban csekély menynyiségben tartalmazzák.

\section{Kreatinkiegészítés}

A kreatinszubsztitúció kizárólag intenzív testi terhelésnek kitett sportolóknál lehet javasolni.

Az egyéni tényezők nagy szerepet játszanak, alapvetően jól reagáló és nem reagáló típust különböztetünk meg. A teljesítménynövekedés tehát nem feltétlenül következik be a kreatinfogyasztást követően. A különböző befolyásoló tényezők, mint például a nem, a táplálkozási szokások (vegetarianizmus), vagy az izom kreatinkoncentrációja a többlet bevitel előtt mind szerepet játszik. Az izomban a kreatinérték növekedése az alacsony kiindulási értékű személyeknél a legkifejezettebb. A tanulmányok azt mutatják, hogy a kreatin a legnagyobb hatást a rövid idejü (3o másodperc), intenzív terhelés (erő és gyorserői teljesítmény) esetén nyújtja, különösen akkor, ha az ismétlődő intervallumokban történik. A szupplementáció célja ebben az esetben az izomban megnövekedett kreatinérték által az ATP-regeneráció javítása, elmondható, hogy a maximális erőkifejtés hoszszabb időn keresztül fenntartható és a fáradás késleltethető.
A kreatinszubsztitúció 30 és 150 másodperc közötti, intenzív terhelés esetén sokkal kisebb hatást fejt ki. Ez a hatás elsősorban olyan terhelések esetén jelentkezik, mint a 100 m úszás és a 400 m futás. Ötből négy, úszókat és futókat vizsgáló tanulmány eredményei nem mutattak pozitív hatást a kreatinszupplementációt követően.

\section{Adagolás és biztonság}

Egyes tanulmányok azt mutatják, hogy öt napon át tartó (feltöltési időszak), naponta $20 \mathrm{~g}$ kreatin bevitele esetén és azt követően 1-2 g/nap dózisfenntartás során növekszik meg az izom kreatinszintje. Megfontolandó azonban, hogy nagy kreatinbevitel esetén a szervezet saját kreatin-előállítása gátolt. A kutatások többsége abszolút dózis meghatározást használ az ajánlások kidolgozásakor a hatékony kreatinkiegészítésre, és nem veszi figyelembe az egyéni testtömeget. Ezért naponta $0,3 \mathrm{~g} / \mathrm{ttkg}$ bevitelt ajánlanak, ezután a kreatinérték fenntartásához pedig öt-hat napon keresztül naponta $0,03 \mathrm{~g} / \mathrm{ttkg}$ felvételt javasolnak. Ugyanez a hatás feltöltő szakasz nélkül is elérhető, ha 3 g/nap hosszabb időn keresztül történő bevitelére kerül sor.

$\mathrm{Az}$ Európai Egészségügyi és Fogyasztóvédelmi Bizottság maximum $3 \mathrm{~g} /$ nap beviteli mennyiség betartását ajánlja. Ennek az az oka, hogy kis számú tanulmány áll rendelkezésre a hosszú távú kreatinfogyasztás mellékhatásaira vonatkozóan, a rövid távú bevitel mellékhatásait pedig még nem kutatták teljes körüen. Az Amerikai Élelmiszer- és Gyógyszerellenőrző Hatóság kreatinkiegészítés megkezdése előtt orvosi konzultációt javasol.

\section{Taurin}

Az aminoszulfonsav a cisztein és a metionin bomlásterméke és az energiaitalok ( $p l$. Red Bull) közismert összetevője. Koffeinnel kombinálva élénkítő hatása miatt népszerü, e hatás azonban kizárólag a nagyon nagy mennyiségü koffeinnek tulajdonítható. A megnövekedett szellemi és testi teljesítőképességet jól megalapozott tanulmányok a taurinra vonatkozóan még nem igazolták. A látszólag pozitív hatásért sokkal inkább más összetevők - mint a koffein - vagy placebohatás felelősek.
A taurint rendszeresen sportolók számára mint sejtvédőt is szokták reklámozni. Tény, hogy a taurin a sejtekben a sejtvédő mechanizmusban (membránstabilizáló) múködik közre, ez a feladat azonban túl van értékelve, amikor antioxidatív hatásáról beszélnek. A német sporttáplálkozás munkacsoportja (DGE) mellékhatások fellépésének lehetősége miatt nem ajánlja a taurin nagy mennyiségű bevitelét. Megfigyelések szerint mellékhatásként negatív változást okozhat például a folyadékfogyasztási szokásokban, valamint az állóképességi teljesítőképességben.

A taurin természetes mennyiségben a halban, a húsban és a tejben fordul elő. Táplálékkal való bevitele nem feltétlenül szükséges, mert a szervezet metionin és cisztein aminosavakból, szintézis útján elő tudja állítani a számára elegendő mennyiséget (5O-125 $m g$ ). Nincs elismert bizonyíték arra, hogy a taurinbevitel hasznos lenne, vagy a sportolók számára az élelmiszerekben természetesen megtalálható taurin mennyisége és a szervezet által szintetizált mennyiség ne lenne elegendő (Raschka \& Ruf, 2017).

\section{Nátrium-bikarbonát}

A bikarbonát (a hidrogén-karbonát szinonimája: $\mathrm{HCO}_{3}$ ) a szénsav ( $\left.\mathrm{H}_{2} \mathrm{CO}_{3}\right)$ sója, a szervezetben a sav-bázis egyensúly szabályozásáért felelős, így a pufferrendszerekhez tartozik. A szénsav/hidrogén-karbonát pufferalkotórésze, ez a fontos puffer gondoskodik a vérben a stabil pH-érték fenntartásáról. A bikarbonát az élelmiszer- és gyógyszeriparban is ismert, nátriummal kötésben a sütőpor (E 5OO) összetevője, valamint pufferként jelen van a gyomorbántalmak elleni tablettákban.

A nátrium-bikarbonát-szupplementáció azon versenysportolók számára ígéretes, akik nagyon intenzív, rövid idejű, anaerob terhelésnek vannak kitéve. Az anaerob terhelés következménye a laktát okozta, az anyagcsere által meghatározott, teljesítménycsökkentő hatású acidózis, amelynek során az energianyerés és az izomkontrakció károsodik. A szervezet az acidózis ellen nagy kiterjedésű pufferrendszerrel védekezik. A szervezet pufferlehetőségeinek kibővítése érdekében kiegészítő pufferoló rendszerekkel, mint például a nátrium-bikarbonát, próbál a savas közeg 
ellen hatni. Ezzel a szervezet potenciálisan hosszabb ideig képes anaerob, tehát nagyon intenzív teljesítményt nyújtani. A bikarbonát pontos hatásmechanizmusa kétségtelenül nagyon komplex, és még alig kutatott.

Az étrend-kiegészítés hatásáról készült tanulmányok eredményei rendkívül különbözők. Bizonyos, hogy anaerob edzéssel az izom pufferkapacitása növelhető. Ebből következik, hogy egy jól edzett sportoló rendelkezik egy, a saját teljesítménymértékének megfelelő pufferkapacitással, így nem profitál a nátrium-bikarbonát-bevitelből. Különösen az élsportolók és a versenysportolók érdekeltek abban, hogy az anaerob kapacitásukat szupplementációval növeljék. Ebből következően a teljesítménynövelés előrejelzése nagyon nehéz, és további kutatásokra van szükség. Ugyanakkor a tanulmányok többsége nagy anaerob terhelés esetén szignifikánsan pozitív hatást mutatott ki a nátriumbikarbonát-kiegészítés mellett. Egy további kutatás arra a következtetésre jutott, hogy a bikarbonát pufferkapacitásával együtt úgy tünik, a nátrium önmagában sokkal inkább hozzájárul a teljesítménynövekedéshez.

\section{Javasolt alkalmazás/ \\ adagolás}

- egyszeri bevitel: 300 mg nátriumbikarbonát vagy citrát ttkg-onként, sok folyadékkal (1 liter) kombinálva, 60-90 perccel a terhelés előtt

- több napon keresztüli bevitel (5 nap): négyszer $100 \mathrm{mg}$ nátrium-bikarbonát/ttkg $(=400 \mathrm{mg} /$ ttkg/nap), a bevitelek között legalább három órának el kell telnie, sok folyadék fogyasztásával

- Bevételi időpont: kb 1,5 órával (3 óráig) a terhelés előtt

A legtöbb tanulmányban alkalmazott, $300 \mathrm{mg} / \mathrm{ttkg}$ mennyiségű bevitel esetén a hatása igazolt, testtömegki- logrammonként o,2-o,4 gramm bevitel javasolt a terhelés előtt. A szupplementáció főként a gyomor-bél-rendszeri bántalmakra hajlamos sportolóknál okozhat hányingert és hasmenést. Számukra a bikarbonátszubsztitúciós lehetőség korlátozott vagy teljesen kizárt. Az intolerancia csökken, ha a bikarbonátbevétel megfelelő mennyiségú vízfogyasztással párosul (Maughan et al., 2018).

\section{Az étrend-kiegészítők \\ alkalmazása}

Napjainkban az étrend-kiegészítők az egyik legdinamikusabban fejlődő termékcsoport, azonban a sportolók számára árult speciális étrend-kiegészítők forgalomba hozatalára, dopping szempontjából történő vizsgálatára vonatkozóan nem áll rendelkezésre hazai jogszabály, az ilyen jellegű termékek számáról, összetételéről nincs hivatalos információ. Emellett a fogyasztók, különösen a sportolók nehezen igazodnak el a termékek között, kellő információk hiányában nem tudják, hogy a termékeket hogyan lehet biztonságosan alkalmazni.

Minden sportolónak orvossal, dietetikussal vagy táplálkozási tanácsadóval történő konzultációt követően megállapított egyéni szükségleteit kell szem előtt tartania az étrend-kiegészítők alkalmazásakor. Ennek ellenére a sportolók gyakran fogyasztanak kontrollálatlanul, orvosi vagy táplálkozástudományi tanácsadás nélkül étrend-kiegészítőket. Némely sportoló táplálkozási ismereteit túlbecsüli, vagy rosszabb esetben helytelen ismeretekkel rendelkezik, így nő a hiányos táplálkozás vagy a túladagolás veszélye. A megadózisban, odafigyelés nélkül fogyasztott étrend-kiegészítők interakciós hatása dokumentált.

Nagy szakértelemre van szükség annak megállapításához, hogy a spor- tolók számára mely étrend-kiegészítők megfelelők, hogyan lehet őket integrálni a sportoló étrendjébe, és hogyan lehet biztosítani, hogy az étrend-kiegészítő-fogyasztásból adódó teljesítménybeli előnyök meghaladják a lehetséges negatív mellékhatásokat. Érdemes kockázat-haszon elemzést végezni, amely magában foglalja a döntéshozatalt a hatékonyságra, a biztonságra és a kockázatokra vonatkozóan, továbbá meghatározza a sportoló számára előnyös termékek csoportját. Egy ilyen elemzéshez jól képzett sporttáplálkozási szakemberre van szükség.

\section{Irodalomjegyzék}

Dickinson, A., Blatman, J., El-Dash, N., \& Franco, J. C. (2014). Consumer usage and reasons for using dietary supplements: report of a series of surveys. Journal of the American College of Nutrition, 33(2), 176-182.

Kerksick, C. M., Wilborn, C. D., Roberts, M. D., Smith-Ryan, A., Kleiner, S. M., Jäger, R., ... Kreider, R. B. (2018). ISSN exercise \& sports nutrition review update: research \& recommendations. Journal of the International Society of Sports Nutrition, 15(1), 38. doi:10.1186/s12970-018-0242-y

Knapik, J. J., Steelman, R. A., Hoedebecke, S. S., Austin, K. G., Farina, E. K., \& Lieberman, H. R. (2016). Prevalence of dietary supplement use by athletes: systematic review and meta-analysis. Sports Medicine, 46(1), 103-123.

Lugasi, A. (2014). Az étrend-kiegészítők kockázati tényezői. Magyar Tudomány, 175(11), 2014.

Maughan, R. J., Burke, L. M., Dvorak, J., Larson-Meyer, D. E., Peeling, P., Phillips, S. M., ... Engebretsen, L. (2018). IOC consensus statement: dietary supplements and the high-performance athlete. British journal of sports medicine, 52(7), 439-455. doi:10.1136/bjsports-2018-099027

Nutrition Business Journal, Supplement Business Report, 2015.

Raschka, C., \& Ruf, S. (2017). Sport und Ernährung: wissenschaftlich basierte Empfehlungen, Tipps und Ernährungspläne für die Praxis. Georg Thieme Verlag. 